\section{Quiet please} Ismail Serageldin deserves the chance to
prepare a new future for the Alexandria library.

$\mathrm{O}$ ne of the defining images of the revolution in Egypt last year was of people linking hands around the Bibliotheca Alexandrina, the modern incarnation of the renowned Library of Alexandria destroyed in antiquity. At the height of the unrest, young people from the city formed a 24 -hour protective cordon to save the library from being over-run by angry crowds.

The Bibliotheca, built close to the site of the original library, is popular with Egyptians, around a million of whom visit the library, the manuscript archives, and the associated museums and galleries each year. The staff organize hundreds of science clubs in Alexandrian schools, and scholars from all over the world give talks and workshops. Its lecture halls are packed most nights and the BioVision life-sciences conference held there last month was massively oversubscribed.

Alexandrians are immensely proud of their library, but some are sceptical of its director, Ismail Serageldin. A long-time champion of rationalism and reform in the Arab world, Serageldin should be an influential voice in the new Egypt. And yet when he speaks, few listen. What offends people most is his closeness to the hated Mubaraks.

Young and old in post-revolution Egypt have found the voice denied to them in 30 years of dictatorial rule and a common mantra is of fresh starts. They will not tolerate the continued presence of people and institutions that prospered during a regime that tortured its own people. Mubarak-era loyalists who seek a place in the new Egypt are parodied as fulool - turncoats. Serageldin is no fulool, but his record as a voice for secular reform is not of much consequence now. For

his critics, what matters is that Mubarak's wife Suzanne chaired the library's board of trustees and that Serageldin accepted a seat in the Egyptian Senate at the request of her husband.

That is why there have been calls in the newly elected parliament for Serageldin to stand down. And it is why, on most afternoons, a small group of protesters stands outside the Bibliotheca, holding a single poster. In red letters are the words "Please leave it". Below the text is an enlarged photograph of Serageldin, his face crossed-out with a large X.

Serageldin retains the support of the library's 26-strong board of international trustees. In practice, however, a decision on his future will be made by Islamist MPs, who dominate the parliament, and by whoever wins the presidency in June. But they should remember that Serageldin's predicament has many parallels in

"Serageldin's predicament has many parallels in Islamic history." made during regimes in the ninth and eleventh centuries $\mathrm{AD}$ that were repressive even by the standards of the time. And yet the scientists who worked for them, such as the mathematician al-Khwarizmi in Baghdad and the polymath ibn al-Haytham in Cairo, are now celebrated as pathfinders. Similarly, Serageldin could not have achieved what he did at the library without the support of the Mubarak regime.

An elected government would be well within its rights to start a new chapter in the library's leadership now. But a wiser course of action might be to allow Serageldin to complete his current term of office and to prepare a succession plan for the end of his directorship in 2015. That would take a lesson from history and honour the contributions of a talented and innovative leader. -

\section{Young Americans}

\section{The rancorous debate over when people first arrived in America has not helped science.}

\section{I} n 1781, American statesman Thomas Jefferson noted that Asia and America are separated "only by a narrow streight" that would have allowed passage between the two continents. There is no record of any scholarly scorn of Jefferson's ideas about the peopling of America. But in recent decades, anyone wading into the topic has needed skin as thick as a woolly mammoth's. The debate over the first Americans has been one of the most acrimonious - and unfruitful - in all of science.

As reported on page 30, one side of that debate held that, around 13,000 years ago, a group of ice-age hunters from Siberia crossed into North America over Jefferson's "narrow streight" - which, at the time, was an exposed strip of land. Armed with stone weapons, called Clovis points, these hunters spread rapidly across the continent and feasted on animals that had never known humans. The opposing camp argued that people reached the Americas long before Clovis technology appeared - at least 1,000 years earlier.

The histories of these arguments are a case study of poor communication and missed opportunities. One researcher, new to the field after years of working on other contentious topics, told Nature that he had never before witnessed the level of aggression that swirled around the issue of who reached America first. "When people stop listening to arguments and stop looking at data and instead just go with their own beliefs," he said, "that's when it becomes completely crazy."

He was referring to researchers who support the Clovis-first model, which was the dominant hypothesis from the second half of the twentieth century until only a few years ago. Researchers who went against that model by reporting even older sites of human occupation endured brutal criticism from opponents who did not give them, or their evidence, a fair hearing. Scientists who supported the Clovisfirst model countered that reports of pre-Clovis sites were examples of poor scholarship.

Studies from the past few years now offer a convincing case that humans reached the Americas well before the Clovis culture. Credit for this breakthrough should go to open-minded archaeologists, who were willing to investigate pre-Clovis sites seriously, and to geneticists, for bringing fresh ideas and techniques to bear on the topic. The recent finds and the shift in the debate have triggered a renaissance in ancient-American archaeology. Researchers are reopening sites, re-examining specimens and searching for new sites to determine who the early pioneers were, and how and when they arrived.

As these ancient events are explored, some archaeologists should examine their recent behaviour. If what they lacked could be summed up in one word, it might be respect. Researchers must always consider that they might be wrong, and should look carefully at opposing data and conclusions. At the same time, scientists who make bold claims must marshal an extraordinary case, especially if they seek to topple a dominant model built on many previous studies. Such prescriptions sound obvious, but many scientists forget them, particularly in fields with limited data, such as archaeology.

The various factions could take lessons from those early Americans $\rightarrow$ NATURE.COM To comment online, click on Editorials at: go.nature.com/xhunqu (whoever they were). These ancient adventurers spurned the well-trodden paths of their forebears to explore new territory. But they would not have succeeded without the help of those who came before and gave them their start. 